\title{
Research, Teaching Heightened by Congressional Experience
}

\author{
Jeffrey R. Biggs, Director, APSA Congressional Fellowship Program
}

W ithin the discipline, "handson" experience as a congressional staffer has never been a sine qua non for doing cutting-edge legislative research or teaching well. But, as linguistic ability or overseas exposure have their advantages for comparative politics, insights gained through completing a staff assignment to a committee or personal staff can enhance the study of the legislative process. APSA's Congressional Fellowship Program has been giving scholars and journalists the opportunity to gain those insights for the past 46 years.

Over the years, former Fellows have spent ten months in Washington, $\mathrm{DC}$, returned to their universities across the country, and many have risen to the top of the discipline with their scholarly work focused on the legislative process. It is a long list, but looking only at former political science fellows who chose to continue their careers in Washington, DC, the list includes Chris Deering of George Washington University, Alton Frye of the Council on Foreign Relations, Tom Mann of the Brookings Institution, Norm Ornstein of the American Enterprise Institute, Candice Nelson and Jim Thurber of American University, and Cathy Rudder, Executive Director of the American Political Science Association, all of whom generously contribute their time to the program.

Expanded diversity of the participants and innovations in the format have made the experience richer through the years, and the 44 Fellows in the 1997-98 class embarked in December on a familiar but exciting path.

The experiences of the political scientists are representative:

Lauren Cohen, Carl Albert Fellow, University of Oklahoma, who secured a position through Senator Edward M. Kennedy's D-MA of- fice on the Senate Judiciary Committee's minority staff;

\begin{abstract}
John Meiers, Carl Albert Fellow, University of Oklahoma, who found a position with the office of Representative Robert L. Ehrlich Jr. (R-MD);
\end{abstract}

Diana Dwyre, Steiger Fellow, assistant professor, California State University, Chico, who accepted a job with Representative Sander M. Levin (D-MI);

Josef J. Braml, International Fellow, Ph.D. candidate, University of Passua, who secured a legislative assistant position with Representative Gary L. Ackerman (D-NY);

Victoria A. Farrar-Myers, assistant professor, University of Texas at Arlington, who worked with Representative Christopher Shays (RCT);

John Haskell, associate professor, Drake University, who accepted an offer from Representative David E. Price (D-NC);

William Koetzle, Ph.D., University of California, Irvine, who landed a spot in the office of Republican Chief Deputy Majority Whip Representative J. Dennis Hastert (RIL).

Their dissertation topics and published scholarly work is a kaleidoscope of legislative interest: Warring Factions: Senators, Interest Groups, and Nominees in the Senate Confirmation Process (Cohen); Capturing the House: Minority Party Strategy and Legislative Process in the 1990s (Meiers); Congressional Campaign Committees and the Nature of U.S. Political Parties (Dwyre with former APSA Fellow Robin Kolodny); The Politics of Shared Authority: The Institutionalization of the American Presidency, 1881-1920 (Farrar-Myers); Fundamentally Flawed: Understanding and Reforming Presidential Primaries (Haskell); and The U.S. Congress: The Impact of Constituency on Electoral and Legislative Behavior (Koetzle).

Rigorous scholarship is foreign to none of the Political Science Fellows, but life in academe has proven far different than life on the Hill. "Every single thing I do is different from life on the college campus," observes Bill Koetzle. "You don't control your environment. Job requirements have short-term deadlines. You're required to become an 'expert' on an issue very quickly, and you're not doing all your own work. You have to work with and through other people."

On the eve of attending an Aspen Institute retreat on the perennial issue of campaign finance reform, Diane Dwyre observed that "some things, strategic-political considerations, for example, seem to matter a lot more in the political world than they do in the scholarly world. There's a real sense of being very cautious about what you say and do on sensitive issues." A participant in the same retreat, Victoria FarrarMyers noted that even though she'd spent years studying the legislative process, "figuring out how to build coalitions and determining what information is relevant, and sitting down with staff of the Office of the House Legislative Counsel to discover how to take care of other Members' objections" is a new experience.

The political scientists are also discovering the all-pervasive influence of the press in Congress. "The extraordinary efforts to groom media skills, pursue media coverage, and tailor messages for media consumption," noted John Meiers, "has been a real eye-opener for me. During my short tenure, I have helped draft an op-ed piece on Iraq, seen how a Member gets profiled in the Washington Post, witnessed the production of the Congressman's local cable television show, and seen my mem- 
ber of Congress gain statewide and national exposure as a potential future Senate candidate. The power of the media (and the lengths to which members seek positive media exposure) to make or break a member of Congress will influence my teaching and research for many years to come."

According to Bill Koetzle, the Political Science Fellows found Congress to be "a gold mine" for research. "The amount of information and type of people you have access to, not only the staff, but with the leadership, is incredible. You also have access to experts at the Congressional Research Service which we'd never be able to get off the Hill."

"You can't do this and not come out of it with a research idea every five minutes," seconded Diana Dwyre. "You'd have to go through the experience blindfolded to avoid it. It doesn't mean that all the ideas are practical, but I already know a lot more about campaign finance reform than I did as a scholar."

John Meiers also called attention to the information available to Fellows. "Awesome informational and technological capacities are provided to the average legislative assistant in order to make that individual the most knowledgeable expert on the staff on a particular issue. The Internet, email, voice mail, the Congressional Research Service, constituent databases, C-SPAN, and hundreds of congressional committee staffers are at your disposal during the entire working day. These tools have suggested to me that one of the most powerful tools Congress possesses is the power to acquire information."

"It's really true," emphasizes Lauren Cohen, "that access to Members, to staff, and to outside authorities makes doing research on Congress a hundred times easier."

Many of the lessons the Fellows have learned will benefit their teaching as well as their research. "One of the things you can learn [from] as a scholar is the legislative efforts that don't pass," noted Victoria FarrarMyers. "The legislative process chart in introductory texts has suddenly come to life for me. I would teach that in an entirely different way in the future. A case as pedestrian as the environmental impact of lowflow toilets has dozens of new implications for the policy process."
"Everybody grumbles about doing constituent mail," she continued, "but you can learn an enormous amount every day about real people with real problems that can be ad-

\title{
1998 Fellow Assignments
}

\author{
SENATE \\ Philippe Ardanaz \\ Micki Aronson \\ E. Andrew Balas \\ Heather Cabot \\ Deanna Caldwell \\ Susan Castro \\ Lynn Cates \\ Lauren Cohen \\ Edward Cole \\ Craig Deare \\ JoAnn Eberle \\ James Fasules \\ Peter Hasselbacher \\ Bruce Hopkins \\ Kevin Johnson \\ David Lessard \\ David Lessard \\ Celia Maxwell \\ Christopher Midura \\ Chase Moseley \\ Daniel Parks \\ Marlon Priest \\ Katherine Schneider \\ Mark Tauber \\ Isbelle Thabault \\ Terrence Williams \\ Laurie Zastrow \\ Budget Cmte., Sen. Pete Domenici (R-NM) \\ Sen. Patty Murray (D-WA) \\ Labor Subcommittee on Public Health and \\ Safety, Sen. Bill Frist (R-TN) \\ Sen. John McCain (R-AZ) \\ Sen. Paul Wellstone (D-MN) \\ Sen. Ron Wyden (D-OR) \\ Labor and Human Resources Cmte., \\ Sen. James Jeffords (R-VT) \\ Judiciary Cmte., Sen. Edward Kennedy (D-MA) \\ Sen. Max Baucus (D-MT) \\ Sen. Bob Graham (D-FL) \\ Sen. Olympia Snowe (R-ME) \\ Sen. John D. Rockefeller IV (D-WV) \\ Finance Cmte., Sen. William V. Roth (R-DE) \\ Agriculture Cmte., Sen. Tom Harkin (D-IA) \\ Sen. Richard Lugar (R-IN) \\ Sen. Frank Lautenberg (D-NJ) \\ Labor Cmte., Sen. Edward Kennedy (D-MA) \\ Sen. Tom Harkin (D-IA) \\ Sen. Richard Durbin (D-IL) \\ Sen. Trent Lott (R-MS) \\ Government Affairs Cmte., Sen. Fred Thompson \\ Judiciary Cmte., Sen Orrin Hatch (R-UT) \\ Sen. Bob Graham (D-FL) \\ Sen. Foreign Relations Cmte. \\ Sen. Frank Lautenberg (D-NJ) \\ Sen. Sam Brownback (R-KS) \\ Sen. Bob Graham (D-FL)
}

\section{HOUSE OF REPRESENTATIVES}

Alison Bolt

Josef Braml

Diana Dwyre

Victoria Farrar-Myers

Naomi Freeman

Jerome Furlow

John Haskell

Bob Hunsinger

Bill Koetzle

Linda Luisi

Ann McCormick

John Meiers

Marcus Pindur

Steven Peterson

Abigail Schirmann

Tina Spann

Kimberley Trent
Rep. Michael Castle (R-DE)

Rep. Gary Ackerman (D-NY)

Rep. Sander Levin (D-MI)

Rep. Christopher Shays (R-CT)

Rep. Ed Markey (D-MA)

Rep. Doug Bereuter (R-NE)

Rep. David Price (D-NC)

Rep. Jim Maloney (D-CT)

Rep. Dennis Hastert (R-IL)

Rep. Howard Berman (D-CA)

Ways and Means Cmte., Health Subcommittee,

Rep. Pete Stark (D-CA)

Rep. Robert Ehrlich Jr. (R-MD)

Rep. Benjamin Cardin (D-MD)

Rep. Steve Largent (R-OK)

Rep. Lee Hamilton (D-IN)

Rep. Corrine Brown (D-FL)

Rep. Carolyn Kilpatrick (D-MI) 
dressed. Students in introductory 101 classes are often cynical about politics. One of the things I'm hoping to do is explain how constituents are relevant and can have an impact on the legislative process."

In addition to fulfilling their responsibilities on the Hill, Fellows organized and hosted a week's orientation for the Canadian Parliamentary Interns in Washington, DC, in April. The Canadians returned the favor in Ottawa, in the annual exchange that dates back to 1973. "For a week in May," observed Journalist Congressional Fellow David Li, "Fellows toured the halls of Ottawa's Parliament Hill and enjoyed a close look at the inner workings of Canadian government. The access to key Canadian decisionmakers was considerable. Members of parliament, policy advisers, journalists, and agency heads freely gave of their time to open a wide window for Fellows to observe the intricacies of Canadian-style parliamentary democracy. From the public political brawl of Question Time to intimate talks with separatist 'Quebecers,' to a tour of Supreme Court chambers, there was virtually no aspect of Canadian government shut off to Fellows. The culture-its form of government, food, language- of some 30 million North Americans is a mystery to too many U.S. citizens. But APSA Congressional Fellows enjoyed front-row exposure to this giant northern neighbor."

The Fellows, at the invitation of the University of Maryland Baltimore County's Maryland Institute for Policy Analysis and Research, spent a day in Annapolis observing the workings of a state legislature.

The Fellows sat in wing-back chairs in the Senate Lounge and engaged in discussions with majority and minority state assembly party members, senior public servants, academics, and journalists.

For all the Political Science Fellows, the APSA Congressional Fellowship has become a surprisingly collegial experience. "People who have already been a Fellow are an automatic connection for us," Bill Koetzle said. "Our group has been good about sitting down and collaborating on ideas such as the use of technology in congressional offices.
Several of us are thinking about a joint project on the role of congressional leadership."

The group of Political Science Fellows has even acquired an international comparative flavor with the inclusion of Marcus Pindur, a former Fulbright Fellow at Tulane University and an M.A. graduate from the Free University of Berlin. Pindur entered APSA's Congressional Fellowship Program as a political journalist for German Public Television and Radio Network (ARD). "From the job interviewing process," Pindur noted, "it was fascinating to see how every office has its own flavor. Members of the U.S. Congress are much more individual political entrepreneurs, and much less shaped by party politics than they would be in Germany, or for that matter, in Europe."

The 1998-99 Class of Congressional Fellows has already been named and will arrive in Washington in November. To learn more about the program and how to apply, visit the CFP web site (www.apsanet.org/ CFP/cfpad.html). 